\title{
戸建住宅における性能可変オイルダンパーを用いた免震システムの設計法 A DESIGN METHOD OF A BASE ISOLATED SYSTEM FOR DETACHED HOUSES USING VARIABLE OIL DAMPERS
}

\author{
根 本 真 孝*，五十子 幸樹**，池 永 昌 容**，井上範 夫**** \\ Masataka NEMOTO, Kohju IKAGO, Masahiro IKENAGA \\ and Norio INOUE
}

\begin{abstract}
In this paper, we propose a design method to control the displacement of base-isolation layer using an oil damper that can change its damping coefficient relative to the displacement. The present damper provides large damping to reduce the response displacement of the base-isolation layer in severe or extreme seismic events, whereas it provides small damping to reduce the response acceleration of the superstructure in moderate seismic events.

A numerical optimization method, sequential quadratic programming, is employed to obtain an optimum set of parameters for the present damper. Design examples show that the base-isolation system with the optimally designed variable oil damper can satisfy the design criteria that cannot be satisfied with a system incorporating a conventional oil damper.
\end{abstract}

Keywords : Seismic isolation, Passive control, Variable oil damper, Displacement control, Base-isolated house, Optimum design method 免震構造, パッシブ制御, 性能可変オイルダンパー, 変位制御, 戸建免震住宅, 最適設計手法

\section{1.はじめに}

1995 年兵庫県南部地震以降、免震建物が普及し、高層建物に限ら ず戸建住宅にも多く適用されるようになってきた。しかし、敷地面 積などの制約から戸建免震住宅では十分な免震層クリアランスが確 保できない場合がある。また、現在、免震建物は主に大地震時にお いて設計クライテリアを満足するように設計されている。しかし、 近年、想定外の巨大地震や長周期地震動の発生の可能性が指摘され ており、これらの地震動により、免震装置の性能限界や免震層クリ アランスを越える過大な免震層変位が生じ、擁壁やストッパーへの 衝突の危険性が愳念されている1) 3)。

免震住宅には摩擦力による減衰を期待しない転がり支承系とそれ を積極的に期待するすべり支承系が存在する。すべり支承は、重量 の小さい構造物を長周期化することに向いていることと、支承材と しての機能に加えて減衰材としての機能を兼ねることで低コスト化 が図れることから、戸建免震住宅に多く用いられている。しかし、 すべり支承による摩擦力は変位に依らず一定であり、履歴ダンパー と同様に免震層変位が小さいときは等価粘性減衰定数が大きく、逆 に免震層変位が大きいときは等価粘性減衰定数が低下してしまう4)。 そのため、中小地震時は応答加速度が大きくなり、巨大地震時は過 大な免震層変位が生じるなどの問題がある。
こうした問題を解決するための免震デバイスとして、性能可変才 イルダンパー(Variable Oil Damper、以下VOD)の開発・研究が行 われてきた5),6)。このダンパーは電源やコンピュータを必要としない パッシブ型でありながら、変位に応じて減衰性能を変化させること のできるものである。これにより、地震動のレベル毎に設定した設 計クライテリアを個別に対象としてきめ細かく設計することが可能 となる。具体的には、中小地震時の応答加速度を低減しつつ、巨大 地震時の過大な免震層変位を抑制するといったように性能が変化し ない従来のダンパーではできなかった設計ができる。

しかし、従来の VOD は両ロッド式で材長が長く戸建免震住宅へ の適用が困難であった。本研究では、戸建免震住宅への適用を目的 として、新たに開発した両ロッド式と同じストロークを有しつつ材 長の短いユニフロー式 VOD の概要について示す。

また、既往の研究ではVODのパラメータをパラメトリックスタデ イにより決定してきたが、VODはパラメータが多いために数多くの ケースに対する解析が必要で、設計に困難を伴った。そこで、設計 者の負担を肩代わりするための手段としてVODの設計に数理計画 法に基づいた最適設計手法例え将8 〜 10)を適用することを提案する。こ れにより、地震動の寸べての入力レベルにおいて設計条件を同時に 満足するVODパラメータを比較的容易に決定可能となる。

\footnotetext{
* 東北大学大学院 大学院生

** 東北大学大学院 准教授. 博士 (工学)

$* * *$ 東北大学大学院 助教 $\cdot$ 博士 (工学)

**** 東北大学大学院 教授. 工博
}

Graduate Student, Graduate School of Engineering, Tohoku University

Assoc. Prof., Graduate School of Engineering, Tohoku University

Assistant Prof., Graduate School of Engineering, Tohoku University

Prof., Graduate School of Engineering, Tohoku University 
本研究では、VOD 付転がり支承免震住宅および VOD 付すべり支 承免震住宅の設計に最適設計手法を適用し VOD のパラメータを決 定する。具体的には VOD 付転がり支承免震住宅の場合では、中小 地震時の応答加速度と巨大地震時の免震層変位を抑制することを目 的とする。VOD 付すべり支承免震住宅の場合では、中小地震時の 応答加速度を犠牲にする代わりにコストを抑えつつ、巨大地震時の 免震層変位を抑制することを目的とする。さらに、それらの結果と 他の減衰材との比較を通じて VOD の有効性について検討を行う。

\section{2.ユニフロー式 $V O D$ 概要}

\section{2-1.ユニフロー式 VOD の開発}

図 1 に両ロッド式とユニフロー式の材長の比較を示す。従来の VOD は、両ロッド式であり、ロッドがダンパー本体の両側を移動 する必要があった。そのため材長が長く、戸建免震住宅の基礎部一 の設置が困難であった。そこで新たに、戸建免震住宅への適用を目 的とし、ユニフロー式 VOD の開発を行った。ユニフロー式 VOD は圧縮時と引張時とで作動原理を変化させることで、ロッドがダン パーの片側のみとなり、両ロッド式と同じストロークを有しながら、 短い材長を可能と寸るものである。これにより、材長を $1.8[\mathrm{~m}]$ (約 1 間)以下とすることができ、戸建免震住宅への適用が容易になる。

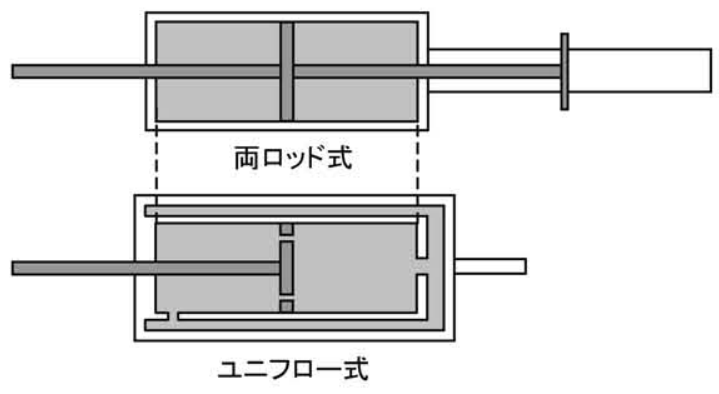

図 1 材長比較

\section{2-2.ユニフロー式VOD機構}

図 2 にユニフロー式VODの機構模式図を示す。このダンパーの特 徵はユニフロー式のオイルダンパーの外部にオイルが充填された小 型シリンダが設置されていることである。免震層に大変位が生じた 際は、これが作動することで、ダンパーカが自動的に上昇する。な お、ロッド端部とその両側の小型シリンダとの間隔は調節可能とな っており、これを設定クリアランス(以下、 $\left.L_{s}\right)$ と称する。

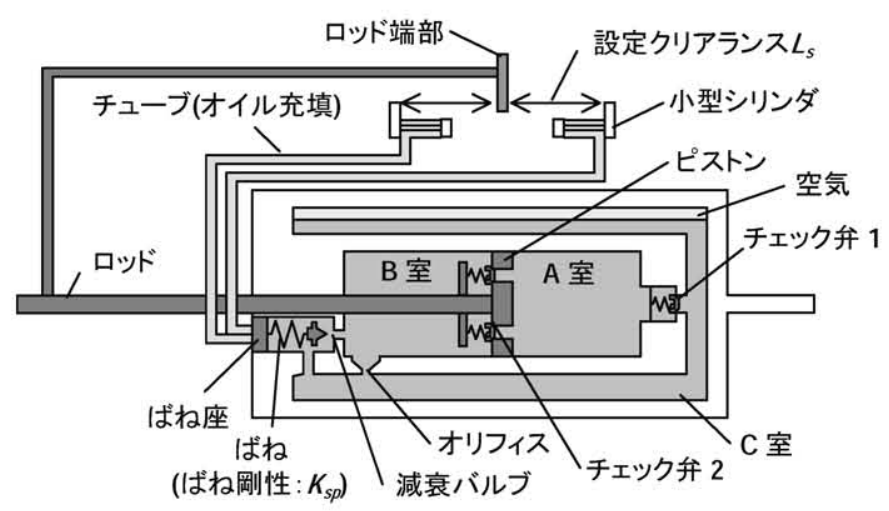

図 2 ユニフロー式 VOD 機構模式図

\section{2-3.ユニフロー式 VOD の作動原理}

ユニフロー式 VOD は圧縮時と引張時でダンパーの作動原理を機 械的に切り替えることにより、短い材長を実現している。図 3 にユ ニフロー式 VOD の圧縮時と引張時における作動原理の比較を示す。 (i )圧縮時

チェック弁 1 は閉じており、 $\mathrm{A}$ 室内のオイルが直接 $\mathrm{C}$ 室に流出す ることはなく、チェック弁 2 を介して A 室から B 室へ移動する。そ れにより、B 室内のオイルが押し出され、減衰バルブとオリフィス を介してC 室へ流出する。

\section{(ii)引張時}

チェック弁 2 は閉じており、オイルが B 室から A 室へ移動するこ とはなく、B 室内のオイルは減衰バルブとオリフィスを介して C 室 に流出する。それにより、C 室内のオイルがチェック弁 1 を介して A 室内に流入する。

以上のように、ユニフロー式 VOD は圧縮時と引張時とで、異な る作動原理を有する。しかし、減衰バルブおよびオリフィスに対す るオイルの流路は常に一定である。これにより、大変位時に小型シ リンダが作動し、減衰バルブを開閉することで、ダンパーカを変化 させることが可能となる。
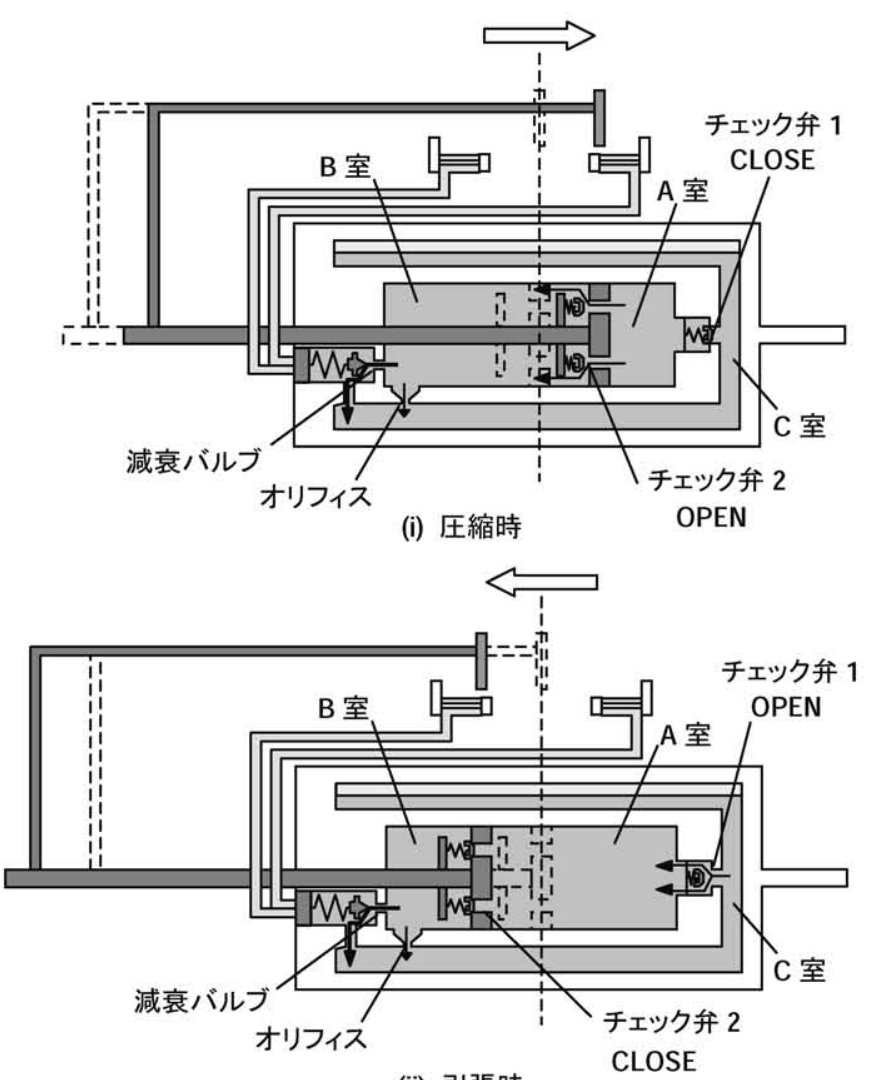

(ii) 引張時

図 3 ユニフロー式 VOD 作動原理

\section{2-4.VOD特性 5)}

VOD の性能変化過程におけるダンパーカ一変位・速度関係の模 式図を図 4 に示す。

\section{(a) 性能変化前}

Lv. 1 地震動入力時など、免震層変位が $L_{s}$ 以下の場合、通常のオイ ルダンパーと同様、速度に比例したダンパー力を発揮する。 


\section{(b)性能変化後}

Lv.2、3 地震動などの入力により、変位が $L_{s}$ を越えると、小型シ リンダが作動し、オイルが押し出される。その油圧により減衰バル ブが閉まり、减衰係数が上昇する。その後、ダンパー力が可変リリ ーフカ $F_{r}$ 以下でダンパー内の油圧が小さいときは減衰バルブが閉じ、 ダンパーカが $F_{r}$ を超えダンパー内の油圧が大きいときは減衰バルブ が開く。それにより、ダンパーカ一速度関倸が 2 折線型となる。な お、 $F_{r}$ はばね剛性 $K_{s p}$ と小型シリンダの作動距離 $X_{c} に よ り$ 決定され、 (1)式で表すように、最大変位を更新するたびに大きくなる。また、 小型シリンダ最大作動時の $F_{r}$ を最大リリーフ力 $F_{\max }$ と称する。

$$
F_{r}=\alpha \times K_{s p} \times X_{c}=\alpha \times K_{s p} \times\left(D_{\max }-L_{s}\right)
$$

ここに、

$$
\begin{aligned}
& F_{r}: \text { 可変リリーフカ } \\
& \alpha: \text { ダンパーの各寸法から決定される比例定数 } \\
& K_{s p}: \text { ばね剛性 } \quad X_{c}: \text { 小型シリンダ作動距離 } \\
& D_{\max }: \text { 最大変位 } \quad L_{s}: \text { 設定クリアランス }
\end{aligned}
$$

である。

なお、VODの設計に際して、 $C_{2}$ は $C_{1}$ に対して 5 倍程度まで設定可 能である。また、 $K_{s p}\left(F_{m \max }\right)$ は他のパラメータに依らず独立に設定で き、最大ダンパーカが過大となり応答加速度が設計条件を越えない 限り、特に制限はない。

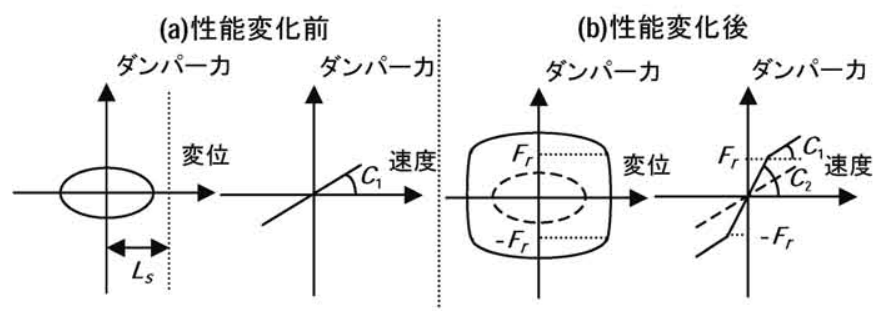

図 4 VOD 力学的特性模式図

\section{3.解析概要}

3-1.解析モデル

解析モデルは、図 5 に示すように免震層のみ違う 4 種類の木造 2 階建て基礎免震住宅を想定する。モデル 1-a は通常のオイルダンパ 一付転がり支承免震住宅を、モデル 2-a は性能が下がるものの低コ ストで最も普及しているす心゙り支承免震住宅を想定している。免震 用オイルダンパーとしては、ダンパー軸力が一定值を越えると減衰 定数を低下させるリリーフ機構を有するものが一般的に用いられて いるが、本論文では簡単のためオイルダンパーは線形粘性減衰要素 として扱う。

モデル 1-b はVOD の性能を最も発揮することのできるVOD 付転 がり支承免震住宅であり、免震層変位と応答加速度の両方を抑制す ることを目的とする。モデル 2-b は普及しているす心゙り支承免震住 宅の免震層変位を抑制することを目的とした VOD 付す心゙り支承免 震住宅である。

表 1 に解析モデルの質量および剛性を、表 2 に免震装置の構成を 示す。なお、基礎固定時の固有周期は $0.50[\mathrm{~s}]$ 、上部構造の減衰定数 は $3[\%] 、$ 階高は $2.5[\mathrm{~m}]$ とし、免震建物時の固有周期は $3.49[\mathrm{~s}]$ であ
る。また、免震層クリアランスは $0.30[\mathrm{~m}]$ とする。VOD の小型シリ ンダの最大作動距離は $0.10[\mathrm{~m}] 、 \alpha$ は 9.2 とする。

すべり支承免震住宅のすべり支承および線形復元材の履歷特性を 図 6 に示す。すべり支承は剛塑性型の履歷特性を有し、摩擦係数は 0.046、免震層変位 $0.30[\mathrm{~m}]$ 時の等価粘性減衰定数は 20 [\%]相当とし、 そのときの等価周期は $2.90[\mathrm{~s}]$ である。なお、等価粘性減衰定数およ び等価周期はそれぞれ(2)式、(3)式から求めた。

$$
\begin{gathered}
h_{e q}=\frac{1}{4 \pi} \times \frac{\Delta W}{W}=\frac{1}{4 \pi} \times \frac{4 \mu m_{\text {total }} g a}{\frac{1}{2} k_{e q} a^{2}}=\frac{2 \mu m_{\text {total }} g}{\pi k_{\text {eq }} a} \\
T_{e q}=2 \pi \sqrt{\frac{m_{\text {total }}}{k_{e q}}}
\end{gathered}
$$

ここに、

$h_{e q}:$ 等価粘性減衰定数

$\mu:$ す心゙り支承摩擦係数

$a$ : 定常変位振幅

$m_{\text {total }}$ : 建物の全重量 $k_{e q}$ : 等価剛性

$T_{e q}:$ 等価周期 $g:$ 重力加速度

である。

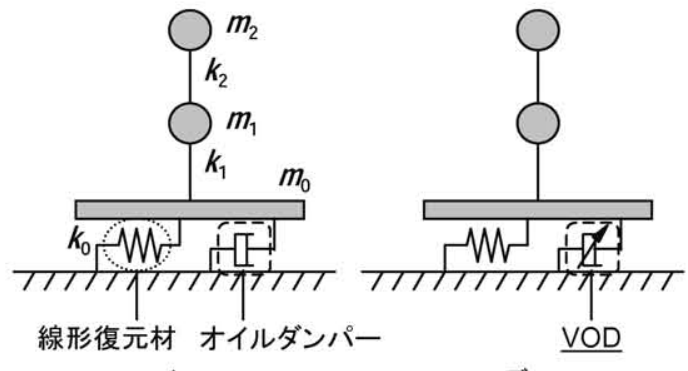

モデル $1-a$

(1)転がり支承免震住宅

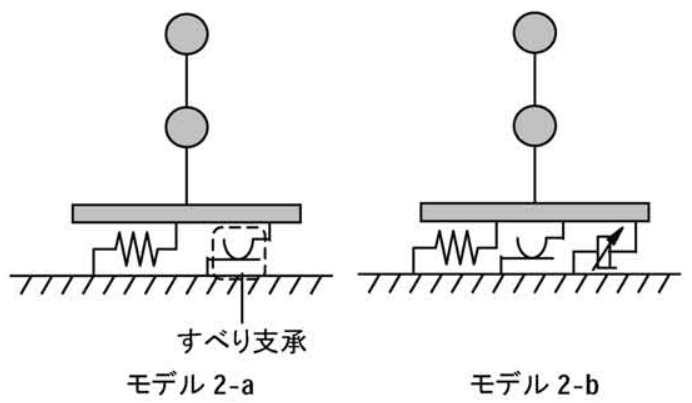

(2)すべり支承免震住宅

図 5 解析モデル

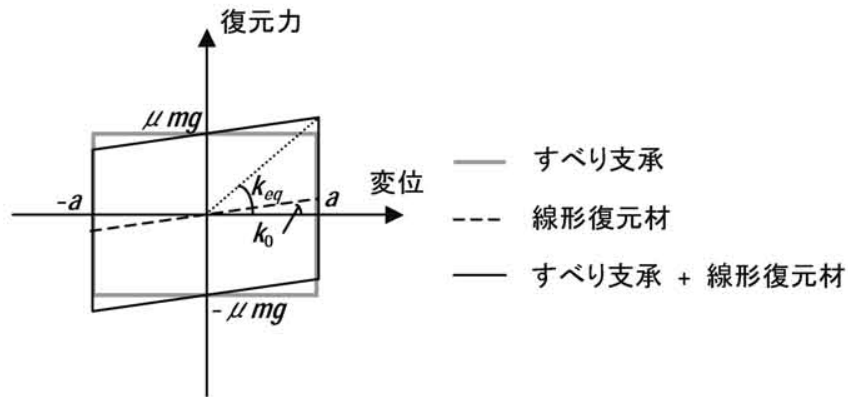

図 6 すべり支承免震住宅履歷特性 
表1 解析モデル諎元 \begin{tabular}{|l|l|l|l|l|}
\hline$m_{0}[\mathrm{kN}]$ & $m_{1}[\mathrm{kN}]$ & $m_{2}[\mathrm{kN}]$ & $k_{0}[\mathrm{kN} / \mathrm{m}]$ & $k_{1}, k_{2}[\mathrm{kN} / \mathrm{m}]$ \\
\hline
\end{tabular}

\begin{tabular}{l|c|c|c|c|c}
\hline 98.0 & 127.4 & 78.4 & 101.7 & 3900 \\
\hline
\end{tabular}

表2 免震装置

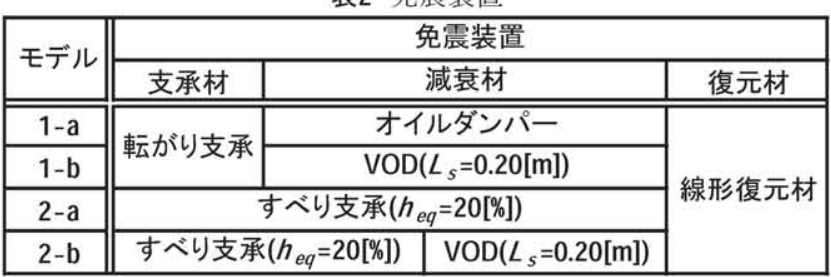

\section{3-2.入力地震動}

解析には表 3 に示寸地震動の PGV をレベル 1(以下、Lv.1)は $0.25[\mathrm{~m} / \mathrm{s}]$ 、レベル 2(以下、Lv.2)は $0.50[\mathrm{~m} / \mathrm{s}]$ 、レベル 3(以下、Lv.3) は $0.75[\mathrm{~m} / \mathrm{s}]$ に基準化して用いる。なお、Lv.3 検討用地震動の鷹取 波および三の丸波に関しては原波を用いることとする。基淮化した 入力地震動の諸元を表 4 に示寸。

ある一組のパラメータで、全地震動に対して 1 度ずつ時刻歷応答 解析を行うことを 1 ステップとし、各入カレベルの最大応答值はそ のレベルにおける全地震動の応答の最大值とする。また、応答值の 算出にはNewmark- $\beta$ 法を用い、 $\beta=1 / 4$ とする。

表3 入力地震動

\begin{tabular}{|c|c|}
\hline 入力地震動 & 呼称 \\
\hline \hline 1968年 十勝沖地震 八戸港湾事務所 EW記録 & 八戸波 \\
\hline 1940年 Imperial Valley地震 El Centro NS記録 & El Centro波 \\
\hline 1952年 Kern County地震 Taft EW記録 & Taft波 \\
\hline 1995年 兵庫県南部地震 JR鷹取駅 EW記録 & 鷹取波 \\
\hline 新東海地震模擬地震動 EW成分 & 三の丸波 \\
\hline
\end{tabular}

表4 入力地震動諸元

\begin{tabular}{|c|c|c|c|c|c|c|}
\hline \multirow[b]{2}{*}{ 入力地震動 } & \multicolumn{2}{|c|}{ Lv.1 } & \multicolumn{2}{|c|}{ Lv.2 } & \multicolumn{2}{|c|}{ Lv.3 } \\
\hline & $\begin{array}{l}\mathrm{PGV} \\
{[\mathrm{m} / \mathrm{s}]}\end{array}$ & $\begin{array}{l}\text { PGA } \\
{\left[\mathrm{m} / \mathrm{s}^{2}\right]}\end{array}$ & $\begin{array}{l}\mathrm{PGV} \\
{[\mathrm{m} / \mathrm{s}]}\end{array}$ & $\begin{array}{c}\mathrm{PGA} \\
{\left[\mathrm{m} / \mathrm{s}^{2}\right]}\end{array}$ & $\begin{array}{l}\mathrm{PGV} \\
{[\mathrm{m} / \mathrm{s}]}\end{array}$ & $\begin{array}{c}\mathrm{PGA} \\
{\left[\mathrm{m} / \mathrm{s}^{2}\right]}\end{array}$ \\
\hline 八戸波 & \multirow{3}{*}{0.25} & 1.19 & \multirow{3}{*}{0.50} & 2.38 & \multirow{3}{*}{0.75} & 3.58 \\
\hline El Centro波 & & 2.54 & & 5.07 & & 7.61 \\
\hline Taft波 & & 2.50 & & 5.00 & & 7.50 \\
\hline 鷹取波 & & & & & 1.27 & 6.57 \\
\hline 三の丸波 & & & & & 0.51 & 1.86 \\
\hline
\end{tabular}

\section{3-3.最適設計手法}

既往の研究では、設計条件を満たすVOD パラメータをパラメト リックスタディにより決定していた。しかし、図4 に示したように VOD にはパラメータが多く、設計条件を満足するように決定する ためには数多くの解析を行う必要があり困難を伴う。

そこで本研究では、最適設計手法を用いてVODの最適パラメータ を決定する。これにより比較的容易かつ論理的に解を求めることが 可能となる。最適設計手法として様々なアルゴリズムが提案されて いるが、本論文では制約条件付き非線形最適化問題に対する最も有 効な数值解析法の一つである逐次 2 次計画法 (Sequential
Quadratic Programming Method, 以下、SQP法) 例えば 8) 10)を用いる。 図 7 にSQP法の解析フローチャート、図 8 に実行可能領域内に目的 関数の極值が存在しない場合を例にとってSQP法の解法の模式図 を示す。

以下に SQP 法の解法手順の概要を示す。

(i) 初期値として、設計変数に $X_{0}$ を代入し時刻歴応答解析により目 的関数 $F\left(x_{0}\right)$ を求める。

(ii) 制約条件の満足状況および最適性の判定を行う。

(iii) 最適性の条件を満足していない場合、 $\left(x_{0}, F\left(x_{0}\right)\right)$ で $F(x)$ に接する 近似 2 次曲面の極值の $\mathrm{x}$ 座標 $x_{1}$ を求める。

(iv) 設計変数に $x_{1}$ を代入し、時刻歴応答解析により $F\left(x_{1}\right)$ を求める。

(v) 目的関数の極值が実行可能領域内に存在寸るときは、近似誤差 が許容値以下になるまで(ii)〜 (iv)を繰り返すことで、最適解を 求めることができる。

(vi) 目的関数の極值が実行可能領域内に存在しないときは、制約条 件の等号が成り立つ点 $x_{2}$ が最適解となる。

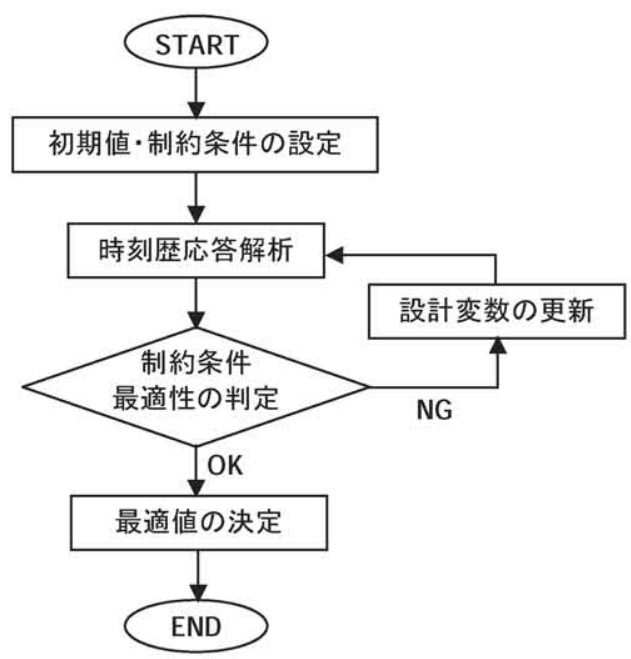

図 7 SQP 法解析フローチャート

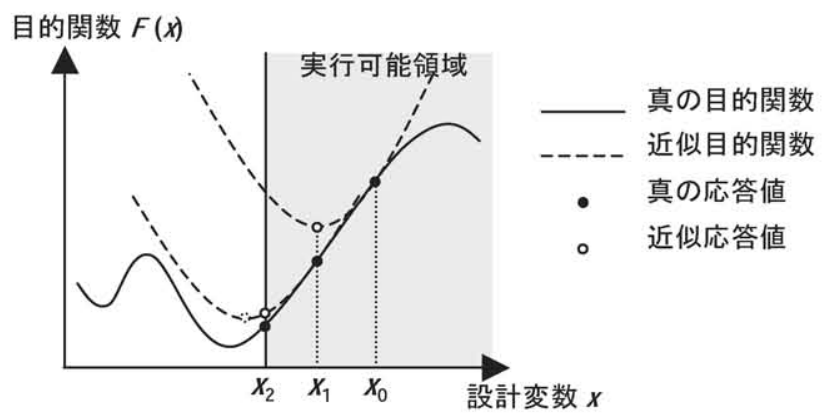

図 8 SQP 法解法模式図

数値最適化の手法は主にオペレーションズ・リサーチの分野で発 展し、構造工学分野では 1960 年にSchmit ${ }^{111}$ が構造最適化に応用し て以降数多くの研究がなされてきているが、本研究のような現実的 な設計問題に数值最適化を応用した例は殆どない。

SQP 法は解の大域的収束性と収束の速さの両面で優れている。ま た、目的関数や制約条件式の導関数が得られない場合に繰り返し計 
算の過程でそれらを近似的に得るので、必ずしも導関数を与える必 要はない。このことから、本論文で扱う問題のように関数が明示的 でない場合に適した解法であると考えられる。

本論文では、SQP法のソフトウェアとしてDOT12)を用いた。また、 本研究で用いるPCの性能はCPUが Intel Core 2 Duo E4400(2.00[GHz])、メモリーが 0.99[GB]である。

\section{4.転がり支承免震住宅に関する検討}

VOD 付転がり支承免震住宅に最適設計手法を適用し、Lv.1、Lv.2 地震動入力時の応答加速度を抑えつつ、Lv.3 地震動入力時における 免震層の過大変位を抑制することを目的として検討を行う。表 5 に 転がり支承免震住宅の設計条件(以下、設計条件 1)を示す。なお、表 中の数值はそれぞれの応答值が満足す心゙き上限値を示している。

表5 設計条件1(転がり支承免震住宅)

\begin{tabular}{|c||c|c|c|}
\hline 入カレベル & $\begin{array}{c}\text { 最大免震層変位 } \\
{[\mathrm{m}]}\end{array}$ & $\begin{array}{c}\text { 最大加速度 } \\
{\left[\mathrm{m} / \mathrm{s}^{2}\right]}\end{array}$ & $\begin{array}{c}\text { 最大層間変形角 } \\
{[\mathrm{rad}]}\end{array}$ \\
\hline \hline Lv.1 & 0.20 & 1.00 & $1 / 200$ \\
\cline { 1 - 3 } Lv.2 & \multirow{2}{*}{0.30} & 2.00 & $1 / 100$ \\
\cline { 1 - 3 } Lv.3 & & 3.00 & \multicolumn{2}{|c}{} \\
\hline
\end{tabular}

\section{4-1.モデル 1-a の最適化}

通常のオイルダンパーで設計条件 1 をすべて満たすことが可能で あるかを検討するため、モデル 1-a に最適設計手法を適用する。

\section{4-1-1.最適化条件}

設計において、応答変位や応答加速度については設計条件を満た していることが重要であり、コストなどの観点から最大ダンパーカ は可能な限り小さいことが望ましい。よって、オイルダンパーの減 衰係数 $C_{d}$ を設計変数に、最小化したい応答值であるLv.3 地震動入力 時の最大ダンパー力を目的関数に、設計条件 1 (表 5)を制約条件とし たとき、本設計問題の標準的な定式化は下記のようになる。また、 多くの数值最適化プログラムは、このような標準形の問題を解くよ うに作られている。これに対する数值解法としてSQP法を用いる。 なお、添え字のiは、Lv.i地震動入力時の最大応答值および制約条件 を示すものとする。

\section{最適設計問題}

$\begin{array}{ll}\text { find } & x=C_{d} \\ \text { to minimize } & F_{\max , 3} \\ \text { subject to } & \left\{\begin{array}{l}D_{\max , i} \leq \overline{D_{i}} \\ A_{\max , i} \leq \overline{A_{i}} \\ R_{\max , i} \leq \overline{R_{i}}\end{array} \quad(i=1,2,3)\right.\end{array}$

\section{4-1-2.解析結果}

最適設計手法を適用し検討を行った結果、設計条件 1 を満たす解 は存在しなかった。その原因を考察するため、C $C_{d}$ を変数としてパラ メトリックスタディを行った。結果を図 9 に示す。

図 9 から通常の免震住宅の減衰 20[\%](図中の灰色の点)では加速 度は設計条件 1 を満たしているが、Lv.3 地震動入力時の最大免震層
変位が設計条件 1 を満たしていない。

一方、Lv. 3 地震動入力時の免震層変位が設計条件 1 を満足するた めには減衰が 75[\%](図中の黒塗りの点)必要である。しかし、それ では Lv.1、Lv.2 地震動入力時の加速度が設計条件 1 を満たさなくな ってしまう。

また、免震層剛性を変化させることで設計条件を満足する可能性 もある。免震建物時の 1 次固有周期 $T_{1}$ を $4.5[\mathrm{~s}]$ とした場合の結果を 図 10 に示す。この結果から、固有周期を 4.5[s]としても設計条件を 満足できないことがわかる。なお、固有周期を $6.5[\mathrm{~s}]$ まで大きくす ることにより設計条件を満足できたが、 $5.0[\mathrm{~s}]$ 以上の長周期とする ことはあまり現実的とはいえない。つまり、免震層剛性を変化させ ても設計条件を満足することは現実には難しいと考えられる。

以上のことから線形のオイルダンパーでは設計条件 1 を満たす現 実的な解は見つからないことを確認した。

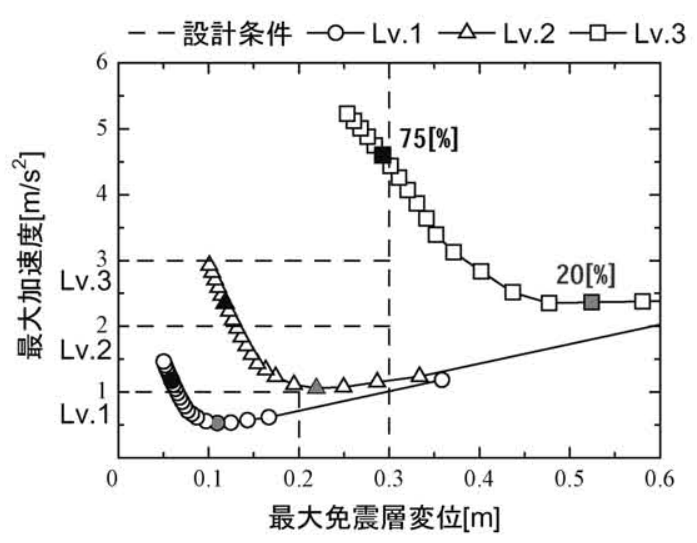

図 9 最大応答值の推移(モデル $\left.1-\mathrm{a} \cdot T_{1}=3.49[\mathrm{~s}]\right)$

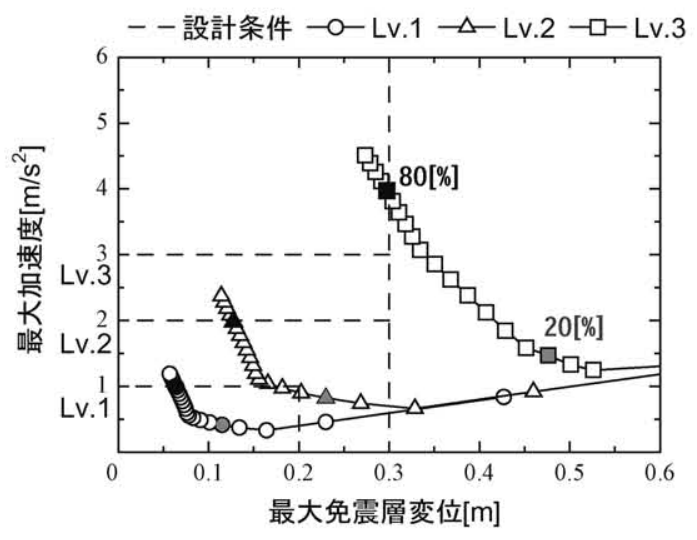

図 10 最大応答值の推移(モデル $\left.1-\mathrm{a} \cdot T_{1}=4.5[\mathrm{~s}]\right)$

\section{4-2.モデル 1-b の最適化}

VOD 付転がり支承免震住宅において、加速度の上昇を抑えつつ、 免震層変位も抑制することを目的とし、地震動の各入力レベルで設 計条件 1 を満足する VOD パラメータを決定するため、モデル 1-b に最適設計手法を適用する。

\section{4-2-1.最適化条件}

設計変数をVODの減衰 $C_{1} 、 C_{2}$ 、および最大リリーフ力 $F_{m \text { max }}$ を決 
定づけるばね剛性 $K_{s p}$ とし、それ以外の条件はモデル 1-aの場合と同 じとして、下記のような最適化問題を定式化し、SQP法を用いて設 計条件を満たすVODパラメー夕を数值的に求める。制約条件は設計 条件 1(表 5) と同じとする。なお、 $L_{s}$ に関してはLv.1 地震動入力時に 性能変化しないようにするため、Lv.1 地震動入力時の免震層変位の クライテリアと同じ $0.20[\mathrm{~m}]$ で一定とする。

\section{最適設計問題}

$\begin{array}{ll}\text { find } & \boldsymbol{x}=\left\{C_{1}, C_{2}, K_{s p}\right\} \\ \text { to minimize } & F_{\max , 3} \\ \text { subject to } & \left\{\begin{array}{l}D_{\max , i} \leq \overline{D_{i}} \\ A_{\max , i} \leq \overline{A_{i}} \\ R_{\max , i} \leq \overline{R_{i}}\end{array} \quad(i=1,2,3)\right.\end{array}$

\section{4-2-2.解析結果}

制約条件付き最適設計問題において、制約条件は等号で満足され る場合と不等号で満足される場合があるが、前者の場合の制約条件 は特に有効制約条件(active constraint(s)) と呼ばれている。一般に、 設計問題には多くの制約条件が課されるが、有効制約となる制約条 件の数は高々設計变数の数となる。制約条件は厳しいものが等号条 件で満足され、制約条件に対して応答值が余裕を持っている場合は 不等号で満足されることとなる。従って、どの制約条件が有効制約 になっているかを調べることで、設計解を決定している条件を知る ことができる。

表 6 には目的関数値を決定づけた入力地震動と有効制約条件およ びそれを与えた入力地震動を、図 11 に表 6 に示した最大応答值の 収束過程を示す。また、得られた最適解を表 7 に示す。なお、解析 には 41 ステップ、 59 分を要した。

表 6 から鷹取波がパラメータの決定に大きな影響を与えているこ と、制約条件としては Lv.3 の応答值が設計解を決定づけていること が確認できる。また、図 11 を見ると、1 ステップ目では、Lv.3 地 震動入力時の最大加速度、最大免震層変位ともに設計条件を満足し ていない。しかし、設計変数を更新し時刻歴応答解析を繰り返して いくことにより設計条件に収束し、41 ステップ目でそれらに対する 制約条件は有効制約となっている。

なお、得られた最適パラメータは $C_{2}$ が $C_{1}$ の約 2 倍となっている。 この比率は、 $C_{2}$ の $C_{1}$ に詨する比の製作上の制約である 5 以下であり、 製作可能範囲内となっている。

以上のように、性能が変化しないオイルダンパーでは条件を満足 する現実的な解が得られないような問題について、最適設計手法を 用いて適切な VOD パラメータを決定することにより、地震動のす ベてのレベルにおいて設計条件を満足することができた。

表6 最大応答值の満足状況 (モデル1-b)

\begin{tabular}{|c||c|c|c|}
\hline & 応答値 & 入力地震動 & 場所 \\
\hline \hline 目的関数 & Lv.3最大ダンパーカ & 鷹取波 & 免震層 \\
\hline \hline \multirow{2}{*}{ 有効制約条件 } & Lv.3最大加速度 & 鷹取波 & 頂部 \\
\cline { 2 - 5 } & Lv.3最大免震層変位 & 鷹取波 & 免震層 \\
\hline
\end{tabular}
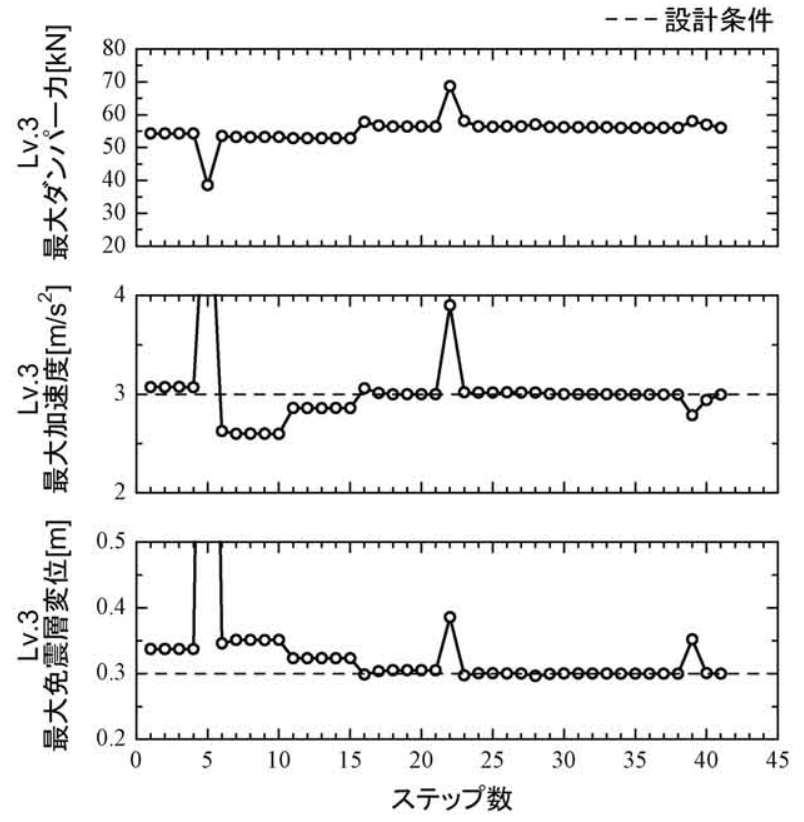

図 11 最大応答值の収束過程

表7 最適パラメータ (モデル1-b)

\begin{tabular}{|c|c|c|}
\hline $\begin{array}{c}C_{1}[\mathrm{kNs} / \mathrm{m}] \\
\left(h_{1}[\%]\right)\end{array}$ & $\begin{array}{c}C_{2}[\mathrm{kNs} / \mathrm{m}] \\
\left(h_{2}[\%]\right)\end{array}$ & $\begin{array}{c}K_{s p}[\mathrm{kN} / \mathrm{m}] \\
\left(F_{r \max }[\mathrm{kN}]\right)\end{array}$ \\
\hline \hline 28.5 & 63.3 & 198.0 \\
$(25.4)$ & $(56.4)$ & $(182.2)$ \\
\hline
\end{tabular}

\section{4-2-3.最大応答值の判定}

図 12 に最大応答值を示す。なお、比較のためにモデル 1 - $\mathrm{a}$ (减衰 定数 20 [\%]一定)の解析結果も示す。また、モデル 1-b の VOD パラ メータは最適設計手法により求めた表 7 の值を用いる。
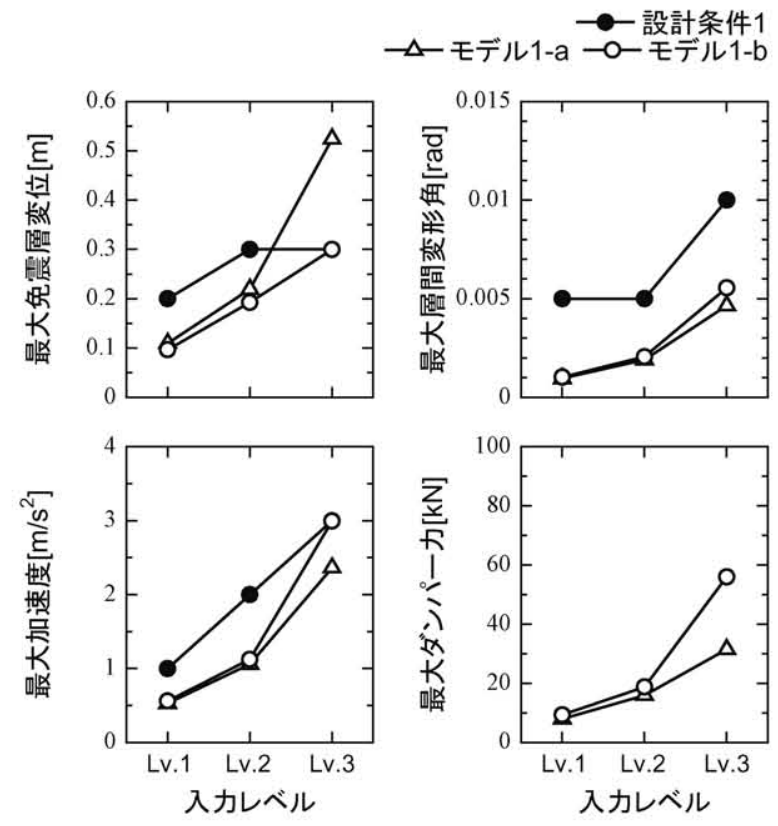

図 12 最大応答值(転がり支承免震住宅) 
モデル 1-a の結果を見ると、図 9 でも示したようにLv.3 の最大免 震層変位が過大となっており、設計条件を満たしていない。

モデル 1-b の結果を見ると、Lv.3 の最大ダンパーカがモデル 1-a に比べ大きくなっているものの、その他の応答值は過大にはなって おらず、すべてのレベルにおいて設計条件を満たしている。

以上より、転がり支承免震住宅に適切なパラメータを設定した VOD を設置することで、Lv.1、Lv.2 地震動入力時の最大加速度を 抑えつつ、Lv.3 地震動入力時の最大免震層変位を抑制可能であるこ とを確認した。

\section{4-2-4.時刻歴応答波形}

通常のオイルダンパーでは設計条件 1 を満足できず、VODを用い ることで設計条件 1 を满足できた理由について時刻歴応答波形から 検討を行う。解析ケースは以下の 3 ケースとする。なお、VODの等 価な減衰定数 $h_{d e q}$ は図 13((4)式、(5)式)に示す方法で算出する。

・減衰 20[\%]一定のオイルダンパー

・減衰 $75[\%]$ 一定のオイルダンパー

・最適設計によりパラメータを決定した VOD

図 14 にダンパーパラメータの決定において影響の大きかった入 力地震動である鷹取波原波入力時の時刻歴応答波形を、図 15 に VOD の履歴ループを示す。

図 14 から減衰 20[\%]のオイルダンパーでは、加速度は設計条件以 内に抑えられているものの、6[s]以降に過大な免震層変位が生じて いることが確認できる。

また、減衰 75[\%]のオイルダンパーでは $6[\mathrm{~s}]$ 以降の免震層の過大 変位は抑制できているが、2〜3[s]および $6[\mathrm{~s}]$ 付近で応答加速度が過 大となってしまっている。

一方、VODを設置した場合を見ると、2〜3[s]では免震層変位が Ls以下であり、性能変化していないため減衰は小さくなっており、 加速度は小さく抑えられている。その後、5[s]付近で免震層変位が $L_{s}$ を越え性能変化しダンパー力が上昇している。6[s]付近では、小 型シリンダの作動距離が小さく $F_{r}$ も小さい。そのため、ダンパーカ が $F_{r}$ より大きくなりリリーフ機構が作動してダンパー力一速度関係 が第 2 勾配にのることにより、等価な隇衰は小さくなっており、応 答加速度が過大となることを防いでいる。さらに、6[s]以降は最大 変位が更新され、小型シリンダがストローク限界近くまで作動し、 $F_{r}$ が大きくなっている。それにより、減衰が $C_{2}$ 一定でダンパーカを 発揮可能となり、免震層の過大変位も抑制することができている。

以上より、VOD は地震動の各レベルにおいて設計条件を満たす ために有効な免震デバイスであるといえる。

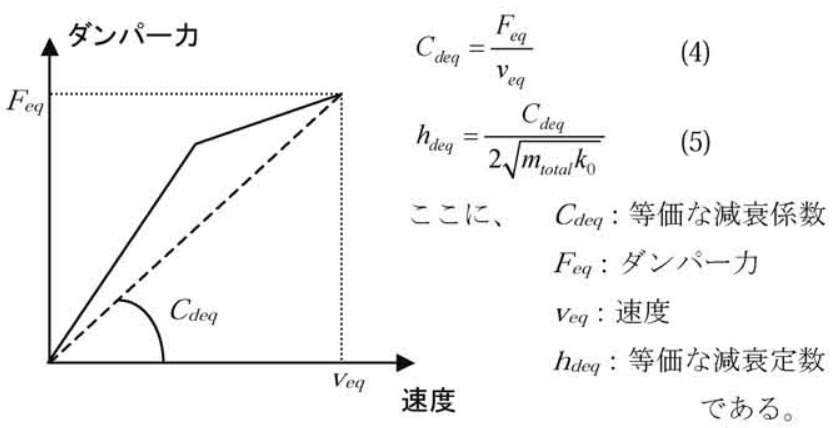

図 13 VOD の等価な減衰定数の算出方法
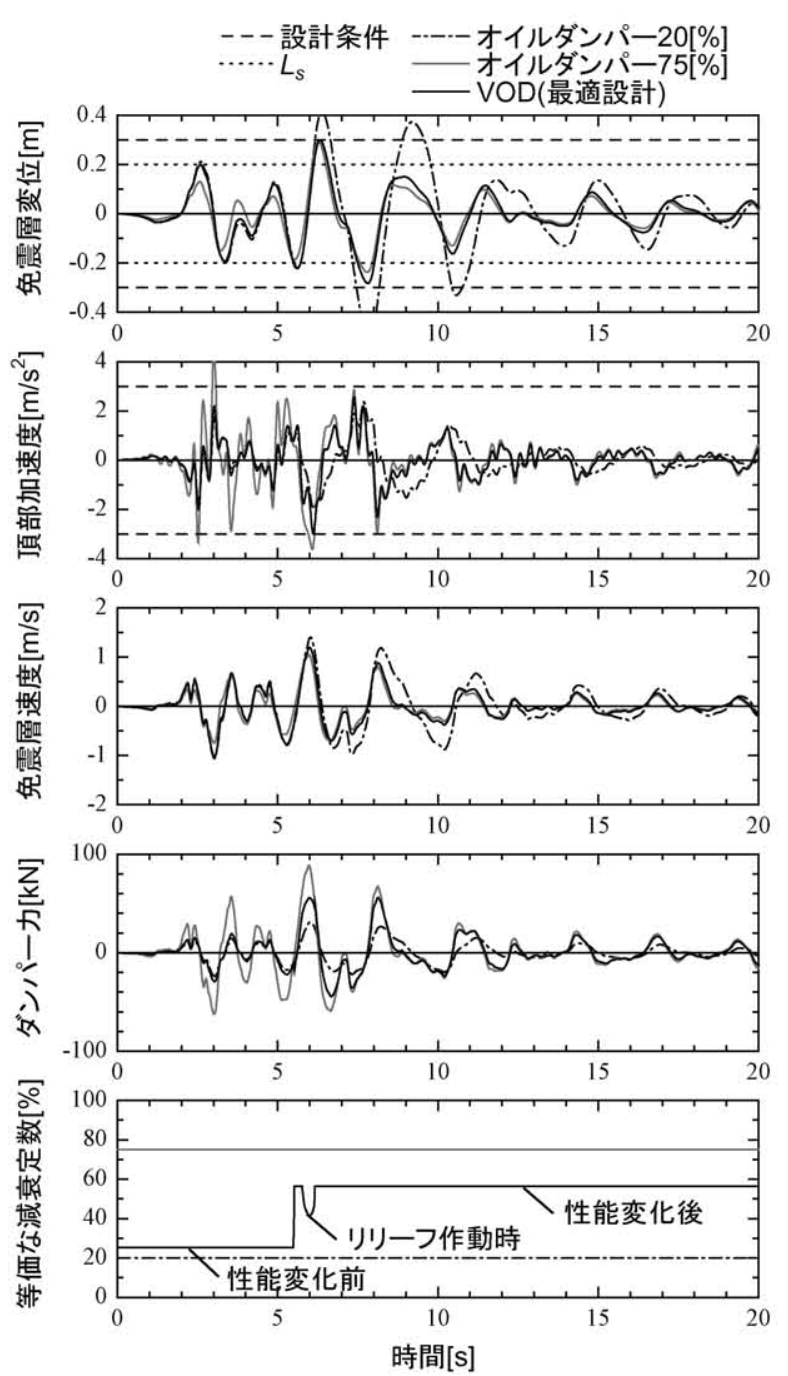

図 14 時刻歴応答波形(鷹取波原波)
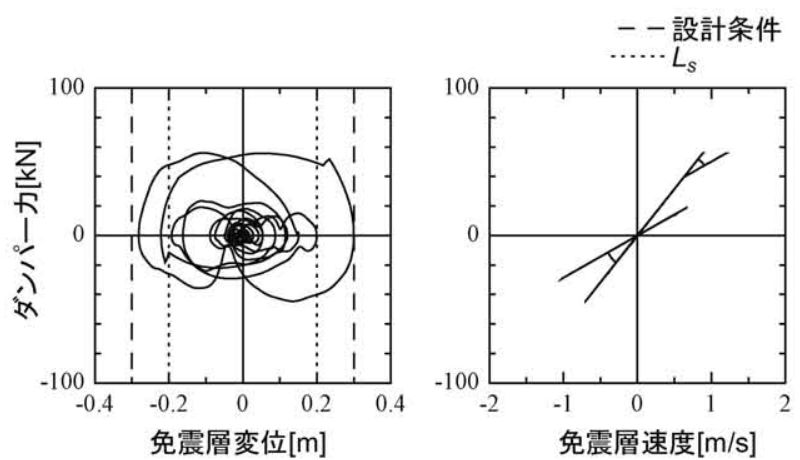

図 15 VOD 履歴ループ(鷹取波原波)

\section{5.すべり支承免震住宅に関する検討}

現在、免震住宅の多くは寸べり支承が用いられている。ここでは、 VOD 付すべり支承免震住宅において、地震動の各入力レベルで設 計条件を満たす VOD パラメータを決定するため、モデル 2-b に最 適設計手法を適用する。なお、すべり支承免震住宅では、低コス卜 である代わりに応答加速度の増大を防ぐことは難しいと考えられる。 よって、応答加速度のクライテリアを大きく設定し、免震層変位を 
免震層クリアランス以内にすることを目的とする。表 8 にすべり支 承免震住宅の設計条件(以下、設計条件 2)を示す。

表8 設計条件2(すべり支承免震住宅)

\begin{tabular}{|c||c|c|c|}
\hline 入カレベル & $\begin{array}{c}\text { 最大免震層変位 } \\
{[\mathrm{m}]}\end{array}$ & $\begin{array}{c}\text { 最大加速度 } \\
{\left[\mathrm{m} / \mathrm{s}^{2}\right]}\end{array}$ & $\begin{array}{c}\text { 最大層間変形角 } \\
{[\mathrm{rad}]}\end{array}$ \\
\hline \hline Lv.1 & 0.20 & 3.00 & \multirow{2}{*}{$1 / 200$} \\
\hline Lv.2 & 0.30 & 3.50 & $1 / 100$ \\
\cline { 3 - 4 } Lv.3 & 0.50 & 4.50 \\
\hline
\end{tabular}

\section{5-1.最適化条件}

モデルは異なるが最適設計問題の定式化はモデル 1-b の場合と同 様とする。また、制約条件は設計条件 2(表 8) と同じとする。

\section{5-2.解析結果}

制約条件の満足状況を表 9 に、得られた解を表 10 に示す。なお、 解析には 29 ステップ、41 分を要した。

表 9 から、モデル 1-b の場合と同様、鷹取波がパラメータの決定 に大きな影響を与えていることが確認できる。また、設計変数の数 が 3 つであるのに詨し、有効制約条件の数が 1 つとなっており、最 適解の与える応答量は設計クリアランスに対して余裕がある状態で あるといえる。

表9 最大応答值の満足状況(モデル2-b)

\begin{tabular}{|c||c|c|c|}
\hline & 応答値 & 入力地震動 & 場所 \\
\hline \hline 目的関数 & Lv.3最大ダンパーカ & 鷹取波 & 免震層 \\
\hline \hline 有効制約条件 & Lv.3最大免震層変位 & 鷹取波 & 免震層 \\
\hline
\end{tabular}

表10 最適パラメータ (モデル2-b)

\begin{tabular}{|c|c|c|}
\hline $\begin{array}{c}C_{1}[\mathrm{kNs} / \mathrm{m}] \\
\left(h_{1}[\%]\right)\end{array}$ & $\begin{array}{c}C_{2}[\mathrm{kNs} / \mathrm{m}] \\
\left(h_{2}[\%]\right)\end{array}$ & $\begin{array}{c}K_{s p}[\mathrm{kN} / \mathrm{m}] \\
\left(F_{r \max }[\mathrm{kN}]\right)\end{array}$ \\
\hline \hline 42.5 & 66.6 & 242.8 \\
$(37.8)$ & $(59.3)$ & $(223.4)$ \\
\hline
\end{tabular}

\section{5-3.最大応答値の判定}

図 16 にモデル 2-a とモデル 2-b の最大応答值比較を示す。なお、 VOD パラメータは表 10 の值を用いる。また、図 16 中の最大滅衰 力はVODのダンパーカとすべり支承による摩擦力の和とする。

モデル 2-a の結果を見ると、Lv.1、Lv.2 地震動入力時の最大免震 層変位は小さいものの、Lv.3 地震動入力時のの最大免震層変位が設 計条件を満たしていない。これは、巨大地震の入力により免震層変 位が大きくなり、等価粘性減衰定数が低下したことが原因であると 考えられる。

モデル 2-bの結果を見ると、VOD を設置することにより、免震層 変位を抑制し、設計条件を満たすことができている。また、応答加 速度に関してはモデル 2-a と比べ、あまり差は見られない。

以上より、す心゙り支承免震住宅に VOD を設置した場合について も、転がり支承免震住宅の場合に比べ、応答加速度の上限值を大き くして制約条件を緩和する必要はあるものの、Lv.3 地震動入力時の 最大免震層変位を免震層クリアランス以内に抑制可能であることを 確認した。
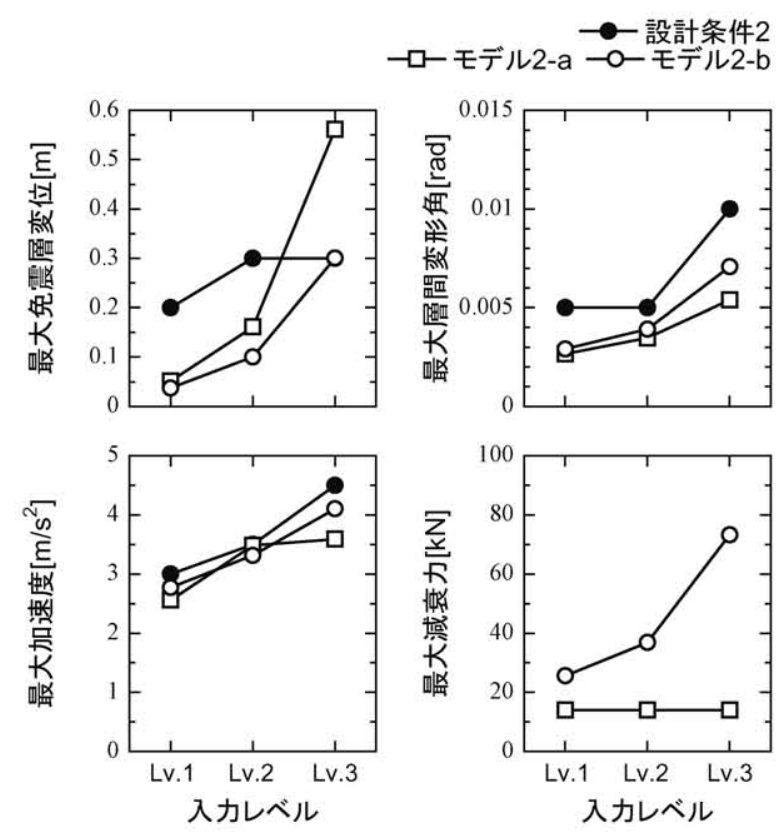

図 16 最大応答值(すべり支承免震住宅)

\section{5-4.制約条件に関する検討}

VOD付すべり支承免震住宅において、設計条件の変化が最適パラ メータに与える影響について検討を行う。設計条件(以下、設計条件 3)については表 11 に示すように、免震層クリアランスを $0.05[\mathrm{~m}]$ 大きくする代わりに、Lv.3 地震動入力時の最大加速度制約を $0.50\left[\mathrm{~m} / \mathrm{s}^{2}\right]$ 小さく設定した。

制約条件の満足状況を表 12 に、得られた解を表 13 に示す。なお、 解析には 120 ステップ、170 分を要した。

表11 設計条件3(すべり支承免震住宅)

\begin{tabular}{|c||c|c|c|}
\hline 人カレベル & $\begin{array}{c}\text { 最大免震層変位 } \\
{[\mathrm{m}]}\end{array}$ & $\begin{array}{c}\text { 最大加速度 } \\
{\left[\mathrm{m} / \mathrm{s}^{2}\right]}\end{array}$ & $\begin{array}{c}\text { 最大層間変形角 } \\
{[\mathrm{rad}]}\end{array}$ \\
\hline \hline Lv.1 & 0.20 & 3.00 & $1 / 200$ \\
\hline Lv.2 & \multirow{2}{*}{0.35} & 3.50 & $1 / 100$ \\
\cline { 1 - 3 } Lv.3 & & 4.00 & $1 / 2$ \\
\hline
\end{tabular}

表12 最大応答值の満足状況(設計条件3)

\begin{tabular}{|c||c|c|c|}
\hline & 応答值 & 入力地震動 & 場所 \\
\hline \hline 目的関数 & Lv.3最大ダンパーカ & 鷹取波 & 免震層 \\
\hline \hline \multirow{2}{*}{ 有効制約条件 } & Lv.2最大加速度 & Taft波 & 免震層 \\
\cline { 2 - 4 } & Lv.3最大免震層変位 & 鷹取波 & 免震層 \\
\hline
\end{tabular}

表13 最適パラメータ(設計条件3)

\begin{tabular}{|c|c|c|}
\hline $\begin{array}{c}C_{1}[\mathrm{kNs} / \mathrm{m}] \\
\left(h_{1}[\%]\right)\end{array}$ & $\begin{array}{c}C_{2}[\mathrm{kNs} / \mathrm{m}] \\
\left(h_{2}[\%]\right)\end{array}$ & $\begin{array}{c}K_{s p}[\mathrm{kN} / \mathrm{m}] \\
\left(F_{r \max }[\mathrm{kN}]\right)\end{array}$ \\
\hline \hline 33.3 & 91.9 & 34.3 \\
$(29.6)$ & $(81.8)$ & $(31.6)$ \\
\hline
\end{tabular}

表 12 を見ると、鷹取波がパラメータの決定において影響が大き な地震動であることには変わりないが、Lv.2 地震動入力時の最大加 
速度を決定する上で Taft 波も重要な地震動であるといえる。また、 設計条件 2 の場合と比べ、有効制約条件が増え、より無䭾の少ない 設計といえる。

次に、得られた VOD パラメータを用いた場合の最大応答值につ いて検討を行う。図 17 にモデル 2-b における設計条件 2 と設計条 件 3 の場合での最大応答值の比較を示す。

図 17 を見ると、免震層クリアランスを大きくすることで、Lv.3 地震動入力時の最大加速度および最大ダンパー力を低減しているこ とがわかる。つまり、免震層クリアランスと最大加速度や最大ダン パーカはトレードオフの関係になっている。この関係に着目すると、 免震層変位と応答加速度のそれぞれの制約条件のバランスを考えな がら設計者がそれぞれの制約条件を厳しくしたり、緩和したりする ことにより、得られる最適解を操作できることがわかる。設計者は、 制約条件の厳しさと得られる最適解のバランスを見ながら望ましい と思う解を選択寸れば良い。著者らはこのように、最適化手法を意 思決定の補助ツールとして位置付ける使い方が一つの理想的な方法 であると考えている。
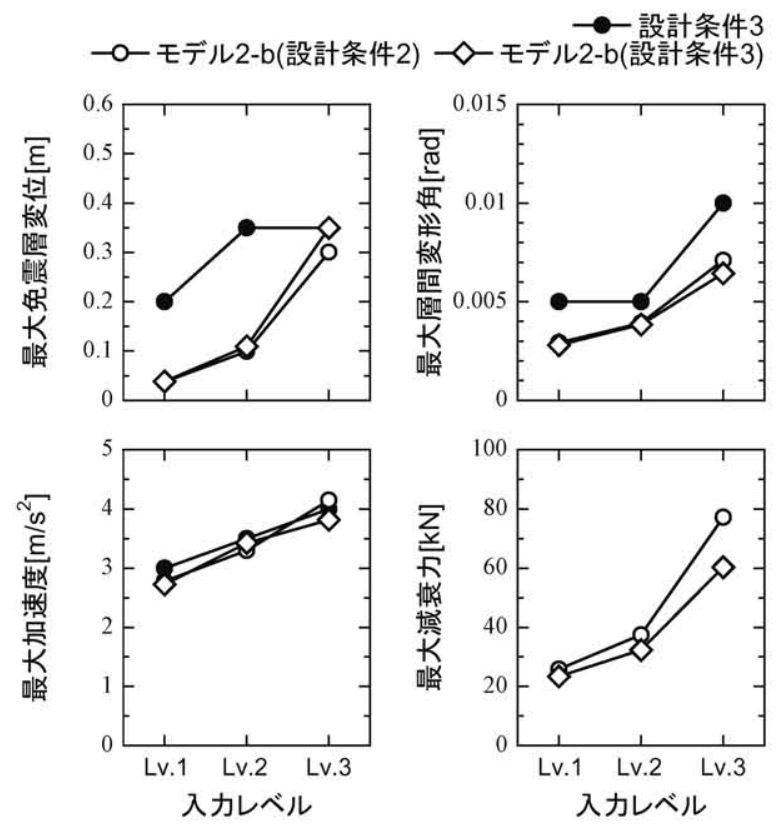

図 17 最大応答值(VOD 付すべり支承免震住宅)

\section{6.まとめ}

本研究では、戸建免震住宅への適用を目的としたユニフロー式 VOD を新たに提案するとともに、VOD 付き免震住宅の設計に最適 設計手法を適用した例を示し、その効果について検討を行った。得 られた結論は以下の通りである。

1) 最適設計手法をVOD 付転がり支承免震住宅の設計例に適用し、 線形のオイルダンパーでは現実的な解が得られないような設 計条件に対して、地震動の全入力レベルにおいて設計条件を満 足する設計解が得られることを示した。

2) 適切なパラメータを設定した VOD 付転がり支承免震住宅なら ば、応答加速度の上昇を抑えつつ、巨大地震に対しても免震層
変位をクリアランス以内にできることを示した。

3）VOD 付すべり支承免震住宅に関しても、最適設計手法を適用 することで、各地震入力レベルに対する設計条件を同時に満足 できることを示した。

4) VOD パラメータを適切に設定することにより、設計者が要求 性能に応じた設計をすることが可能となることを示した。

以上より、転がり支承免震住宅およびすべり支承免震住宅に最適 設計手法に基づいて設計した VOD を設置することで、Lv.1 から Lv.3 までのすべての地震入力レベルにおいて設計条件を満足する 設計が可能であることを例示した。

\section{謝辞}

本研究は、平成 20 22 年度 科学研究費補助金 研究基盤(B)「性 能可変オイルダンパーにより長周期巨大地震時の免震建物過大変位 を抑制する技術開発」(課題番号 20360246、研究代表者 井上範夫) の一部として実施しました。また、ダンパーの開発には、(有)シズ メテックに多大なご協力をいただきました。解析において愛知県設 計用入力地震動研究協議会の作成波(三の丸波)を使用させていただ きました。

ここに記し、謝意を表します。

\section{参考文献}

1) 日本建筑学会 : 長周期地震動と建築物の耐震性, 2007.12

2) 中安誠明, 中島正愛 : 過大地震下における免震建物の応答と損傷, 日本 建築学会大会学術講演梗概集 B2, pp.441-442, 2003. 9

3）飯場正紀, 緑川光正, 花井勉, 皆川隆之 : 変位抑制部材を用いた免震層 衝突時における免震住宅の地震時応答, その 1,2 , 日本建築学会大会学 術講演梗概集 B2, pp.425-428, 2004.8

4) 五十子幸樹, 中井川敦, 堀則男, 井上範夫, : ダンパーの作動原理の差 異と免震装置のばらつきが免震建物の応答性状に与える影響に関する 検討, 日本建築学会東北支部研究報告集, 第 72 号構造系, pp.152-156, 2009.6

5) 田部井直哉, 堀則男, 井上範夫 : 性能可変オイルダンパーの開発および 免震構造物一の適用性, 日本建築学会構造系論文集, 第 636 号, pp.259-266, 2009.2

6) S. Mehdi Dehghan B., Norio Hori, Norio Inoue: Study on Base Isolated Structure with Variable Oil Damper, Proceedings, 14 WCEE, Beijing, CD-ROM Paper-ID 05-06-0034. 2008.10

7) 愛知県設計用入力地震動研究協議会 : 愛知県設計用入力地震動の作成, 想定地震による強震動予測，概要版(改訂版)，2006.2

8) 福島雅夫 : 数理計画入門 システム制御情報ライブラリー，朝倉書店, 1996.

9) G. L. Nemhauser, A. H. G. Rinnooy Kan and M. J. Todd (eds.): Optimization: Handbooks in Operations Research and Management Science, Vol.1, Elsevier, 1989. [邦訳(伊理ほか監訳), 最適化ハンドブッ ク, 朝倉書店, 1995.]

10) G.N. Vanderplaats: Numerical Optimization Techniques for Engineering Design, McGraw-Hill, 1984.

11) Schmit, L.A.: Structural Design by Systematic Synthesis, Proceedings, $2^{\text {nd }}$ Conference on Electronic Computation, ASCE, New York, pp.105-122, 1960

12) Vanderplaats Research \& Development, Inc., Design Optimization Tools Users Manual, 5.7, 2001

(2010年 8 月 5 日原稿受理, 2010 年10月 25 日採用決定) 